FORUM

\title{
ATTEMPTING A DIALECTICAL RECONCILIATION OF THE CONCEPT TRUTH IN THE OBJECTIVISM OF EVANGELICAL CHRISTIANITY AND THE RELATIVISM OF POSTMODERNISM
}

\author{
E.K. Foshaugen ${ }^{1}$
}

\begin{abstract}
The Church faces a number of challenges concerning the sociological impact postmodernism is having on society. One significant area that has been profoundly disputed is the epistemological content of the concept of truth. Evangelical Christians believe in Objectivism: the conviction that there exists some ahistorical source, foundation or framework to which we can appeal to in determining the substance and nature of truth, knowledge, reality, right or wrong - and it is independent and external to personal experience or thinking. However, many no longer believe in absolute truth but in relativism. Relativism is the denial that there exists such an ahistorical source or foundation that we can appeal to. Truth, knowledge, reality, right and wrong are all concepts that are relative to a specific conceptual scheme, framework, or paradigm founded in a society, religion and culture. This article represents an endeavour to dialogically reunite the two perspectives by arguing for the seeking of the "truths" in both perspectives. God is Objective Truth and has become involved in history: in the existential; in the material setting of our relative and infallible thoughts and the slanted interpretative experiences of the Triune God and life. The synthesis will be an affirmation that for Christians Truth is discovered and revealed in fellowship within community. And members of the Body of Christ are first and finally called to reveal and demonstrate truth to the world — in their unity.
\end{abstract}

1 Dr. E.K. Foshaugen, Chaplain at King Edwards School, 1 Preston Cottages, Petworth Road, Witley, Surrey, GU8 5SD, UK. E-mail: ekfoshaugen@hotmail.com 
As a minister of God's Word, trained in the evangelical Baptist and Reformed traditions, I want to uphold the value and relevancy that all Scripture is God-breathed and is useful for teaching, rebuking, correcting and training in righteousness. This means that I believe in the existence of universal absolute truth. However, for many years I have been uncomfortable with the definition of absolute truth. My own excursion in the academic worlds of theology, philosophy and psychology, my exposure to other cultures and perspectives and my daily experiences reveal ongoing changes in my beliefs and values. How am I going to reconcile the absolute truths I believe in and the claims that all truth is relative? Maybe some of our "absolute truths" are relative?

I have a number of hypothesis or premises that I will develop in this article as I attempt to merge objectivism and relativism in terms of truth claims: ${ }^{2}$

- Unity in the community of the Church (John 17:21: the prayer of Jesus for unity that is desire, life, purpose, love) is "the final apologetic" (Schaeffer 1970:17) to the truth of God and His love. People are challenged to respond to and believe what they see and experience. Unity is the most convincing apologetic to persuade the world of the truth of Christianity and of the truth of Jesus' claims. Thus the Church "reveals and demonstrates" truth through the unity it exhibits.

- The Revealer (God) and His revelation might be objective but the reader of Scripture is not infallible and so Scripture awaits open, humble, honest and careful study done in community.

- Christians are often guilty of loving their "truths", that is their own ecclesiastical organizations and traditions, their own rituals and creeds, more than they love each other.

Anne Butler (Aunty Anne to me) told me a story about myself as a 6 year old child in her Sunday school class. She had shared the story of Jesus feeding the 5000 with 5 loaves of bread. She explained that

2 My doctoral thesis "Worship and spirituality as a praxis-orientated apologetic in a postmodern world — an incarnational engaged approach" explores them in detail. 
5000 people were many times more than the 30 odd children listening to her story. I told her that she was a liar. To my young mind this was incomprehensible as my two brothers and I ate one loaf of bread for lunch. Since I can recall it has been my nature to question things; to doubt and ask questions. And I have discovered that answers only give rise to more questions. This has resulted in me having many opinions that I hold to and a few but very important convictions that hold me. I can live (sometimes very reluctantly and painfully) with paradox and ambivalence whilst believing in the objective Divine Revealer and collective shared absolutes.

I am a practical theologian. Practical theology studies the means by which the Church as the community of faith preserves and protects its identity. In one sense it is a theology of practice and a dialogue between theology and praxis. Thus theology should move in a circle between theory and practice, and practice and theory, with Scripture always informing and guiding the process. My opinion is that all theological thinking is in one sense essentially practical if it is to be relevant. For me theology is not only the study of the knowledge of God. It is also the study of the process of getting to know God. This process requires all the help available and as long as the social sciences can aid this endeavour and not be allowed to control the process or overrule Scripture then there is an important place for them. Theology's field of study embraces all factors essential to knowing God.

Practical theology concerns itself with the way in which the gospel works out in practice in the world and should raise questions about what it sees, addressing them back to theology. Practical theology is a discipline that must bring to bear theological criteria on contemporary situations and realms of individual and social action and beliefs, then attempt to formulate a suitable response and test the theory in practice.

The challenge facing me (and perhaps some others who like me are Socratic and always examining their lives and their theology: who have learnt that questions and the journey is often as important as the answers and the destination) is the sociological impact postmodernism is having on the society I live in. And one very big area 
that has been heavily challenged is the epistemological content of the concept of truth. The majority of people I meet no longer believe in absolute truth. Truth is seen as a sociological conditioned perspective. Truth is relative.

So what is this relativism that is permeating western society today? To understand relativism one needs to attempt to define some of the tenants of postmodernism. McGrath (1996:184) defines postmodernism as follows:

Postmodernism is generally taken to be something of a cultural sensibility without absolutes, fixed certainties or foundations, which takes delight in pluralism and divergence, and which aims to think through the radical "situatedness" of all human thought.

Tarnas (1991:395) notes an appreciation of the plasticity and constant change of reality and knowledge, a stress on the priority of concrete experience over fixed abstract principles, and a conviction that no single a priori thought system should govern belief or investigation, as key principles. This naturally calls into question traditional notions of truth, structure and reality. The centre of discourse is dislocated to the edges of human preference and subjectivity. People are increasingly attributing thinking and actions to their cultural background. Thomas Kuhn (1962) questioned the concept of any absolutes in science. He reviewed the history of science and argued that scientists work in terms of paradigms (or worldviews). These models are derived from a network of presuppositions, and through them the facts of experience are interpreted. This reflects sciences' biases concerning the nature of reality and knowledge. Tarnas (1991: 396) writes:

The mind is not the passive reflector of an external world and intrinsic order, but is active and creative in the process of perception and cognition.

Reality eludes all attempts at conformity so there can never be any absolute foundation. Reality is constructed by the mind and not simply perceived by it. If reality is a fluid, unfolding process then the quest for knowledge is endlessly self-revising, continually affected and moulded by one's actions and beliefs. All human understanding is interpretation and no interpretation is final. Reality is in some 
sense constructed by the mind, not simply perceived by it, and many such constructions are possible, none necessarily sovereign. I think postmodernism would define truth as "All truth is a social construct, pragmatically justified and community sourced and based".

The question facing people today is: "Is there an ultimate standard by which we can judge competing concepts of truth and actions or is it all relative?" To begin to answer this let me define key terms.

Objectivism is the conviction that there exists some a-historical (outside of history) source, foundation or framework to which we can appeal to in determining the substance and nature of truth, knowledge, reality, right or wrong that is independent and external to personal experience or thinking.

Relativism is the denial that there exists such an a-historical source or foundation that we can appeal to. Truth, knowledge, reality, right and wrong are all concepts that are relative to a specific conceptual scheme, framework, or paradigm founded in a society, religion and culture. Truth is not fixed, universal or objective.

Subjective truth is defined as being dependent on a perceiving, experiencing, contemplating mind for existence, reality or validity.

Rationalism in the narrow sense excludes experience as a source of truth. Truth is established by reason.

For many Christians the Bible and Christian teaching is objective. God is unchanging and all questions of truth, knowledge, reality, right and wrong, are ultimately decided from the divine point of view. Reformed and evangelical Christianity subscribes to some form of objectivism.

I am not sure that I can express unqualified acceptance of objectivism. Church history and my own experience reveal that many Christians have confused the a-historical with the historical. They often reflect their viewpoint as if it is revelation revealed by God. Fundamentalists (defined as those who reject all forms of critical scholarship), individuals and even many denominations (in their applaudible desire to promote orthodox doctrine) often have tradition or culturally determined doctrines that are presented as "The Gospel". This exclusivistic presentation has hurt many (e.g., apartheid). However, I believe in the biblical tradition that Christians serve an a-historical omniscient Creator who has revealed Himself and His will through Scripture and through the life, death and teaching of the incarnate 
Jesus Christ. For me God is the ultimate source for truth, knowledge, values, reality, etcetera. This is non-negotiable. So how do I reconcile objectivism with relativism? Maybe a dialectical approach - a synthesis of the two is possible?

Most Christians think that they have to choose between objectivism and relativism. This article will attempt to show that it is a false choice. These are not the only two options. Some in the Christian community have attempted a dialectically produced synthesis of objectivism and relativism.

Before we examine this process lets spend some time understanding the philosophical process they are applying.

G.W.F. Hegel famously applied the term "dialectic" to his philosophical system. For Hegel, there is a coalescing metaphysical process underlying the apparent diversity of the world, which he called the dialectic. This process is in essence the necessary emergence of superior and more acceptable theory or hypothesis out of a conflict between less developed and less adequate solutions. Hegel supposed that the evolution of hypothesis occurs through a dialectical process - that is, a concept gives rise to its conflicting and contradictory opposite, and as a result of this divergence, a third view, the synthesis, arises. The synthesis is at a higher level of truth than the first two views. Hegel's work is based on the idealistic conception of a universal mind that, through evolution, seeks to arrive at the maximum level of selfawareness and freedom.

An example of the application of Hegel's philosophy can be found in the thinking of Karl Marx. The German social and political theorist applied the notion of dialectic to social and economic processes. He conceived historical progress as a matter of the progress of technology (of human productive forces) to the point where this development came into disagreement with the existing system of ownership and exchange of land, labour, and goods (the existing social relations of production). At this point the contradiction takes the form of a struggle for power between two classes, one of which represents the development of the productive forces, and the other the maintenance of the existing social relations of production. The former eventually succeeds in overthrowing the latter in a revolution, so that the deve- 
lopment of the productive forces can continue (communism). Thus history as a whole has a dialectical movement. Progress towards human mastery over nature, and eventually towards the elimination of all class relations, results from the development and resolution of contradictions.

Traditionally, this dimension of Hegel's thought has been analysed in terms of the categories of thesis, antithesis, and synthesis. Although Hegel almost never used these terms, they are helpful in understanding his concept of the dialectic. The thesis, then, might be a concept that contains within itself incompleteness that gives rise to opposition, or an antithesis, a conflicting concept or form of consciousness. As a result of the conflict a third concept arises, a synthesis, which overcomes the conflict by reconciling at a higher level the truth contained in both the thesis and antithesis. This synthesis becomes a new thesis that generates another antithesis, giving rise to a new synthesis, and in such a fashion the process of metaphysical or historical development is continually generated.

Now let us note how some have applied this dialectical system. John Hick (1980) believes that one day in the future we will have a broader world theology. Hick (1980:8) comments:

Such a theology would consist of theories or hypothesis designed to
interpret the religious experiences of mankind, as it occurs not only
within Christianity, but also within the great streams of religious
life, and indeed, in the great non-religious faiths also, Marxism and
Maoism and perhaps - according to one's definition of "religion"
- Confucianism and Buddhism. The project of a global theology
is obviously vast, requiring the cooperative labours of many indivi-
duals and groups over a period of several generations.

Hick is saying that various interest groups, religions and individuals will present their theories and hypothesis for dialogic examination. Through a dialectical process they will work towards a consensus for a "world theology".

Another way of applying Hegel's dialectic process is seen in the work of Knitter. Knitter (1985:225) contends that all the world religions evolve out of the micro phase of religious history in which they grew. Religions consolidated and established themselves in comparative seclusion from each other. Now we are in a macro phase of world 
history and each world religion can now develop and comprehend itself only through interrelating with other religions. In the past religions knew little of the other religions but are now through globalisation existing along side each other.

Both Hick and Knitter are proposing the evolving and development of a singular global theology through the dialectical process and historical consensus. It would appear that they are asking Christians to realise that whilst we do not now have the concepts and norms for a global or world theology we must apply relativism so that we can have objectivism - eventually. Truth is relative and might become universal one day.

Hick and Knitter both take the historical process seriously. Their dialecticism is searching for norms and values that will help to adjudicate between competing human claims and opinions on truth, knowledge etc. However, these norms will arise out of the historical interaction of cultures, religions etc. They are not sourced in an a-historical foundation.

I wish to propose that we Christians should have the conviction that truth, knowledge, reality, etc. is found in the objectivism stance that God is the a-historical source of these concepts. However, whilst upholding God as the ultimate source and revealer of truth, values, knowledge, reality, etc., I think we should take seriously the lessons that postmodern relativism has to offer. In fact I would suggest that many are implicit in Scripture. Christians are members of the body of Christ - a community of fellowship. In this community we are called by God to discern His will for ourselves, our community (the Church) and the larger community we are placed in. This is a biblical imperative. God's nature and will is revealed to us through Jesus (and interpretation of Scripture) in our community. In this community we mature in our knowledge of God and His will. This is a very important point. Here we can learn lessons from postmodern ideology without having to forgo all our concepts of truth.

In John 17:21 Jesus calls for unity. In this prayer Jesus prays for the oneness of the Church. This oneness would be a powerful witness to the reality of God's love. Sanders and Mastin (1985:376) relate this oneness to the unity of relationship between the Father and the 
Son that was a relationship of love, trust, and unity of purpose. By the expression of these characteristics in the Church the world will come to see the results of Jesus' activity and believe the Father sent him.

The manner of this unity is the interdependence between the Father and Son. The Church is called to model this interdependence, this creative diversity within the Trinity. It is not primarily an outward, physical ecumenical unity, but unity of a spiritual nature (Hendriksen 1961:364). The Trinity is not only the model or manner of this unity; it is the cornerstone. Mitchell (1990:341) calls it "internal unity". It is not organizational unity or man made affiliations.

Unity in life with God should evidence itself in unity within all Christians. Whilst recognizing denominations and ecclesiastical distinctions, Christians are all one in Christ. The spirituality of the Church should reflect an internal unity in desire, in life, in purpose, and in love. This unity does not require that all Christians have the same liturgy or believe precisely the same things. It is not a forced conformity. It does mean that Christians must be wary of loving their own ecclesiastical organizations and traditions, their own rituals and creeds, more than they love each other.

Whilst most commentators might define this unity as internal, or supernatural, or spiritual, it is always to have an outward expression. The reason for this is simple. Christianity cannot expect the world to believe that God sent Jesus, that the claims of Jesus are true; that Christianity is true, unless the world sees the reality of the oneness of true Christians.

The postmodern world no longer believes in the objective concept of truth and is certainly not interested whether an individual's doctrine is correct or not. The postmodernist is concerned with spirituality and experience. If the Church can live and experience what Sloyon (1988:198) calls a unity of "right faith"; a living organic oneness that flows from the action of God and is revealed in the Church, the postmodernist is challenged to respond to and believe what it sees and experiences.

The gift of God, unity, is rooted in the being of God, and manifests as love one for another (John 13:33-35). Unity with God and unity with those united to God are complimentary and as Beasley- 
Murray says, "One without the other is inconceivable" (1991:112). This unity that Jesus prayed for will convince the world of the truth of Christianity and of the truth of Jesus' claims.

Schaeffer (1970:16) does not believe the world will ever judge Christianity on the content of its teachings but on the love Christians show to one another. He writes:

Yet, without true Christians loving one another, Christ says the world cannot be expected to listen, even when we give proper answers (1970:17).

He calls the observable love of Christians for Christians "the final apologetic".

I advocate an ultimate reference point that is not the human consensus that Hick and Knitter are looking for. I am saying that all human consensus must be ultimately evaluated by the objectivism that maintains an a-historical source for truth, that is God the Father. However, I am also endorsing the reality that we are participators in a community of discernment and in this community we all are working towards the objective of a consensus that upholds His revelation and is pleasing to Him. This is an ongoing process and here the lessons that postmodern ideology can teach us are valuable. We need to recognise the various influences on us as we strive to determine and practice God's will. We are called to be in an unremitting dialogic process in a dialogic community. When we disagree we work together to find consensus and mutually acceptable solutions. In partnership with God and each other we dialogue to facilitate our fellowship in our community and our mission in the world. We acknowledge that variance over many fundamental issues are an inevitable fact of life under current circumstances. We should not be arrogant with our claims on truth and being exclusivistic without being humble and honest in admitting our radical situatedness as we seek to interpret God's revelation and will and mature in and with our community is wrong.

Unity in the Church is founded upon the above mentioned premises and on the following theses or realities I now wish to explore. Firstly, the Revealer (God) and His revelation might be objective, but the reader of Scripture is not infallible and so Scripture awaits open, humble, honest and careful study. Secondly, the Church "reveals and 
demonstrates" truth through the unity it exhibits. The Holy Spirit guides open-minded readers to the truth in Scripture. We conform our experience to truth (through rational enquiry in community) and must be wary of the tendency to confirm truth by our experience. Experience is always partial, subjective, selective, relative and subject to interpretation - it is not normative. Yet, experience does matter and our truth pronouncements must take experience into account. People react to what they observe and encounter (that is one reason why Jesus emphasised unity). Furthermore, the Christian God is presented as a living immanent loving Father (and all the benefit that involves) to be encountered. However, experience without rational inquiry is not always enough to determine truth. My personal observation is that in a postmodern world experience is very important and we no longer need a water tight apologetic (100\% pure deductive logic) but rather a reasonable explanation that bests suits the experience. Perhaps another article is needed to clarify this. In essence I believe that the Christian worldview best explains the existential questions of the day. One could say that Christianity offers the most valid hypothesis. However, we need to earn the right to be heard and people need to experience the power of the gospel and the unity and love that the Church has to offer.

Truth is objective, but our understanding of it might be partly affected by the way we look at it. Let us recognise that often reality is our own perspective and presuppositions. Frequently when we say "You are wrong" we are not saying it on biblical grounds (whilst we might claim so) but on the implicit subjective basis that "Your view differs from mine". I have met and read so many who claim to have the absolute complete final interpretation and meaning of all the Scripture for a given existential or doctrinal issue. To me this is arrogance (which I realise you could say I am now guilty of). Exegesis often becomes eisegesis as they actually read meaning into the text. I think that the text of Scripture often challenge the pre-understandings brought to them. Interpretation is done within the community (the Church). Scripture was written by individuals in communities, was canonised by individuals in communities and interpreted throughout the centuries by individuals in communities. The individual in the community presents his/her interpretation to the community to 
interact with other interpretations of members of the community and the community tradition. Communities present their interpretation to one-another. All this is done in the light of Scripture and the prayer of Jesus for unity. This is how relativism and subjectivism can be overcome to some extent. Individuals in communities that interact with other communities and individuals, develops critical reflection and awareness that results in better interpretation, understanding and application of God's word.

There are two stories that we need to take cognisance of when considering truth. The Bible is God's story. Then there is our story. These two stories are intertwined - we are paragraphs in the same story. God's story is objective and our stories are relative (subjective). We are intelligent rational beings and thus we reflect on the stories. We codify our deductions into propositions narrated as our dogma, doctrines or systematic theology. We do this to talk about our experiences and to express what we believe. On the other hand, we must always remember that our systemizing is done in a context; a cultural linguistic milieu. Systematic theology is done with past or contemporary methods of deliberation, ideas, insights and assumptions that are limited, incomplete and conditioned. This can affect deduction and conclusions and elucidates why conclusions differ. There exists no one single universal systematic theology. People with different presuppositions and assumptions can have dissimilar conclusions. Thus a systematic theology is partial insight, reflection or perspective of the whole.

Theology is based on God's story (objective) and our story (relative). This is a significant insight in a postmodern world where people approach truth from life experiences and not dogma. That is why we need to have a high Christology (the divinity of Jesus Christ) but also a low Christology (the humanity of Jesus Christ). High Christology tends towards propositions and creeds - Jesus hands down truth whilst a low Christology reveals the very human story of Jesus who uncovers life's truth. Systematic theology some times tends to engage the intellect and not always the whole person that is heart and mind. Theology flows from the narratives. It aids us in discovering deeper conclusions than might initially be grasped. When "doing" theology let us remember that humility, openness, recognition of the 
relative nature of our story versus the objective nature of God, context, time and retrospection can often reveal deeper motifs and/or revive lost themes. (The story of Martin Luther and Protestantism is an example. Another is the story of the Church during apartheid).

Thus I define truth with a description. "Truth is $\mathrm{g}(\mathrm{G}) \operatorname{ood} \mathrm{n}(\mathrm{N})$ ews that is life altering. Truth has life - it can set one free". I affirm the objectivity and the divine revealed cognitive nature of Scripture whilst allowing for the possibility of my personal error in my understanding of Scripture. I do not only have the revelation in a book but experience the Revealer Himself. It is I who am relative and He who is objective. It is very important to remember that when truth comes to us our response is not automatic. We have choices - to accept or reject, believe or disbelieve. Our choices are also influenced by our presuppositions, beliefs, experiences, culture, attitudes - that make up our personhood. Each of us is a unique and complex community formed being with God given freedom and so we will not necessarily respond identically to any given truth. This does not mean we are back to relativism and subjectivism as we do not have total power to shape truth (especially when we are in dialogical relationship in the Church community). Truth has power to shape us - to free us. Our relationship with truth is two-ways. It shapes us and we shape it. Having an unpresumptuous and informed concept of objective truth hopefully ensures that we are more shaped by truth than shaping truth.

Our experience of the Objective (the Triune God and the Word) is relative and in the community of believers we seek to discover and apply that which is objective. Sometimes we get it right and sometimes we mess up. Truth is propositional yet personal; it is historical, a-historical and existential. It is factual yet relational. Truth is eternal and it is life yet can be lost, forgotten or subjective in its interpretation, application or relevance. The truths about truth (objectivism and relativism) is that they are not necessarily conflicting, contradictory and irreconcilable but they are synthesisable - complimentary and enrich, supplement and deepen each other. God has revealed Himself in the written Word and through personal experiences. The history of the relationship between the Triune God and all created humans reveals one truth. The Eternal and Infallible One who is Objective Truth has become involved in history: in the exis- 
tential; in the concrete situadedness of our relative infallible thoughts and subjective experiences of life. We who are God's beloved must walk in humility and grace as we together seek to interpret and live the will of the Father for His Church and all His creation. The members of the Body of Christ are first and finally called to reveal and demonstrate truth — in their unity.

\section{BIBLIOGRAPHY}

\section{BeAsLey-Murray G R}

1991. Gospel of life: theology in the Fourth Gospel. Peabody: Hendrickson.

\section{HENDRIKSEN W}

1961. Commentary on the Gospel of John. London: Banner of Truth Trust.

\section{Hick J}

1980. God has many Names: Britain's new Religious pluralism. London: MacMillan.

\section{KNITTER P F}

1985. No other name? A critical survey of Christian attitudes toward the world religions. Maryknoll, N.Y.: Orbis Books.

\section{KUHN T}

1962. The structure of scientific revolutions. Chicago: The University of Chicago Press.

\section{McGrath A}

1996. A passion for truth. Leicester: Apollos.

\section{Mitchell J G}

1990. An everlasting love: a devotional study of the Gospel of John. Oregon: Multnomah.

SANDERs J N \& MAstin B A

1885. The Gospel according to John. London: A \& C Black.

\section{SCHAEFFER F A}

1970. The mark of a Christian. Illinois: IVP.

\section{SLOYAN G}

1988. John. Atlanta: John Knox Press. 
Foshaugen

The concept truth

TARNAS R

1991. The passion of the Western mind. London: Pimlico.

Keywords

Truth

Objectivism

Postmodernism

Evangelical Christianity
Trefwoorde

Waarheid

Objektivisme

Postmodernisme

Evangeliese Christendom 


\section{INSTRUKSIES VIR OUTEURS}

1. Manuskripte kan in Afrikaans, Engels, Nederlands of Duits voorgelê word en moet verkieslik nie langer as 7000 woorde wees nie.

2. Manuskripte kan per gewone pos of per e-pos aan die redakteur gestuur word.

3. Alle bydraes word deur keurders op akademiese gronde gekeur. Skrywers word uitgenooi om die name en adresse van drie tot vier persone wat as beoordelaars gebruik kan word, voor te lê. Die redaksie probeer om ten minste een hiervan te gebruik. Keuring geskied altyd anoniem.

4. Manuskripte word vir publikasie oorweeg met dien verstande dat die redakteur die reg voorbehou om veranderinge aan te bring wat hy as wenslik beskou om die styl en aanbieding in ooreenstemming met die beleid van die redaksie te bring. Indien aansienlike veranderings nodig is, sal die manuskrip na die skrywer terugverwys word vir regstelling of goedkeuring.

5. Manuskripte moet in eerste instansie persklaar, in finaal geredigeerde, sorgvuldig taalversorgde en volledig afgeronde vorm voorgelê word.

6. Die titel moet so kort en bondig moontlik wees.

7. Artikels moet verkieslik verdeel word in onderafdelings met gepaste opskrifte. Opskrifte en subopskrifte moet met Arabiese syfers genommer word, byvoorbeeld 3 word gevolg deur 3.1, 3.1.1 en 3.1.1.1 (tot hoogstens die vierde vlak).

8. Alle artikels moet voorsien word van 'n taalversorgde abstract ('n opsomming in Engels) van nie langer as 150 woorde nie. 'n Afrikaanse opsomming is opsioneel.

9. Aan die einde van die artikel moet drie tot vier trefwoorde in sowel Engels as Afrikaans bygevoeg word. Die trefwoorde moet so gekies word dat dit die navorsingsveld waarbinne die artikel val en die spesifieke bydrae wat die artikel maak, akkuraat weergee.

10. Afkortings en akronieme moet nie in die normale teks gebruik word nie. Akronieme wat algemeen gebruik word, byvoorbeeld VSA, is egter aanvaarbaar. Afkortings kan wel in voetnote en tussen hakies gebruik word. 
11. Slegs kursivering (nie vetdruk nie) mag as aanduiding van beklemtoning of van 'n woord of uitdrukking uit 'n ander taal of van die titel van 'n boek gebruik word.

12. Aanhalings korter as 20 woorde word tussen aanhalingstekens as deel van die gewone teks geplaas. Aanhalings langer as 20 woorde word as 'n aparte paragraaf ingekeep en nie binne aanhalingstekens geplaas nie.

13. Bronverwysings in die teks moet verkieslik in die Harvardstyl geskied, met slegs die skrywer se van, as volg: (Young 2004:231) of Young (2004:231) beweer dat...

Let op: Geen komma na outeur se van.

Geen spasie na dubbelpunt.

By verwysing na werke van Klassieke of Middeleeuse outeurs word die naam van die outeur, die Latynse/Griekse titel van die werk (kursief), en die boek, hoofstuk, paragraaf of reëlverwysing (in Arabiese syfers met punte tussenin) vermeld, byvoorbeeld:

Vergilius (Aeneïs 12.601) of Cicero (de Officiis 1.13.2).

14. Aanhalings en bronverwysings in voetnote word op dieselfde wyse as aanhalings en bronverwysings in die teks hanteer (Kyk 12 en 13).

15. Bibliografiese besonderhede word in die literatuurlys verskaf en nie by wyse van voetnote nie. 'n Volledige bibliografie in die Harvardstyl met alle relevante besonderhede, in die vorm van 'n alfabetiese lys volgens outeur, moet dus verskaf word. Slegs werke waarna in die teks van die artikel self verwys word, moet in die bibliografie opgeneem word. Die volgende dien as riglyn:

Artikels:

VAn JaArsveld F J \& Janse VAn Rensburg J

2002. Godskonsepte tydens pastorale gespreksvoering. AcTh 22(2):179-197.

Let op: Geen komma na van.

Geen punte na voorletters.

Gebruik hoofletters in titel net waar absoluut nodig.

Slegs titel van tydskrif in kursief. 
Geen spasies tussen volumenommer, dubbelpunt en bladsynommers.

$\mathrm{U}$ is welkom om afkortings te gebruik vir tydskrifte, maar indien $\mathrm{u}$ vermoed dat die leser nie sal weet na watter tydskrif u verwys nie, kan u dit voluit skryf.

Boeke:

Vos J S

2002. Die Kunst der Argumentation bei Paulus. Studien zur antiken Rhetorik. Tübingen: Mohr Siebeck. WUNT 149.

Let op: Geen komma na van.

Geen punte na voorletters.

Gebruik hoofletters in titel net waar absoluut nodig.

Slegs titel van boek in kursief.

Geen spasie voor dubbelpunt na plek van uitgawe.

Die reeks waarin die boek verskyn word heel aan die einde genoem en nie tussen hakies geplaas nie.

Artikels in boeke met ' $n$ redakteur:

ACHTEMeIER P

1997. Finding the way to Paul's theology. In: J. M. Bassler (ed.), Pauline theology. Vol. 1. Thessalonians, Philippians, Galatians, Philemon (Minneapolis: Fortress, SBLSS 4), pp. 3-21.

Let op: Die verwysing is feitlik dieselfde as vir 'n gewone boek, behalwe dat "In:" bykom, die redakteur(s) genoem word en die verwysing na die plek van uitgawe, uitgewer en reeks binne hakies geplaas word sodat die verwysing na die bladsynommers makliker lees. Verder word pp. gebruik.

Koerantberigte:

Indien outeur nie aangedui word nie:

DIE KERKBODE

2001. Aborsie nie aanvaarbaar. 15 Junie, p. 23.

Indien outeur wel aangedui word:

SMIT M

2002. Die pad vorentoe. Die Volksblad 23 Julie, p. 2. 
Instruksies vir outeurs

Indien persoon betrokke aangedui word:

Asmal K

2003. Nuwe onderwysbedeling. Die Volksblad 4 Desember, p. 9.

Webbladsye:

Webbladsy (met outeur en publikasiedatum aangedui)

Le Roux K

2002. Teologie in 'n nuwe eеu. [Aanlyn] Bekom van: http://www. kerk.org.za/bib/dokumente/3.html [2003, 5 Januarie].

Webbladsy (geen outeur)

Teologie in 'n nuwe eeu. 1989. [Aanlyn]. Bekom van: http://www.kerk. org.za/bib/dokumente/3.html [2003, 5 Januarie].

Webbladsy (met outeur; geen publikasiedatum)

\section{Le Roux K}

n.d. Teologie in 'n nuwe eeu. [Aanlyn]. Bekom van: http://www. kerk.org.za/bib/dokumente/3.html [2003, 5 Januarie].

16. Die skrywer van 'n artikel ontvang 10 oordrukke van sy artikel sowel as een gratis eksemplaar van die betrokke uitgawe van die tydskrif.

17. Aangesien Acta Theologica'n geakkrediteerde tydskrif is, word 'n bedrag van R50 per bladsy vir bladgelde gehef. Die koste vir 'n artikel kan uit die verdienste op navorsingsuitsette verhaal word. Outeurs dra dus nie self die koste van artikels nie. Rekeninge word aan outeurs gestuur vir voorlegging aan die bestuur van die universiteit of enige ander instansie waar die outeur werksaam is. 


\section{INSTRUCTIONS TO AUTHORS}

1. Manuscripts can be submitted in Afrikaans, English, Dutch or German, and should preferably not exceed 7000 words.

2. Manuscripts may be submitted to the editor by ordinary post or by e-mail.

3. All contributions are reviewed on academic grounds. Authors are invited to submit the names and addresses of up to four persons as referees. Refereeing is always anonymous.

4. Manuscripts are considered for publication provided that the editor reserves the right to make such alterations as he sees fit to accommodate the style and presentation to the editorial policy. Should extensive changes be necessary, the manuscript will be returned to the author for correction or approval.

5. Manuscripts are to be submitted in the first instance ready for the press: finally edited, stylistically polished and carefully proofread.

6. Titles should be as short and concise as possible.

7. Articles should preferably be divided into subsections with suitable headings. Headings and subheadings should be indicated by means of Arabic figures, for example 3 being followed by 3.1, 3.1.1 and 3.1.1.1 (at most).

8. All articles must be provided with an edited abstract (a summary in English) not exceeding 150 words. An Afrikaans summary is optional.

9. Three to four key words in both English and Afrikaans should be provided at the end of the article. These should accurately render the discipline in which the article is written as well as the specific contribution of the article.

10. Abbreviations and acronyms should be avoided. Acronyms in current use, for example USA, are acceptable. Abbreviations can be used in footnotes and between parentheses.

11. Italics (not bold) may only be used to indicate emphasis, a word or expression from another language, or the title of a book.

12. Quotes shorter than 20 words are placed in quotation marks as part of the text. Quotes exceeding 20 words form a separate paragraph indented without quotation marks. 
13. References in the text should preferably be in the Harvard style, mentioning only the author's name as follows: (Young 2004:231) or Young (2004:231) alleges that ...

Note: No comma after the author's surname.

No space after the colon.

References to works by Classical or Middle Ages authors should mention the name of the author, the Latin/Greek title of the work (italics), and the reference to the book, chapter, paragraph or sentence (in Arabic figures with full stops), for example:

Vergilius (Aeneis 12.601) or Cicero (de Officiis 1.13.2).

14. Quotations and references in footnotes are similar to quotations and references in the text (See 12 and 13).

15. Bibliographical details are provided in the literature list and not in footnotes. A complete bibliography in the Harvard style must be provided, giving all relevant details. All sources must be listed alphabetically by authors' surnames. Only works referred to in the text should be listed in the bibliography. The following is a guideline:

Articles:

VAN JAARSVELD F J \& JANSE VAN RENSBURG J

2002. Godskonsepte tydens pastorale gespreksvoering. AcTh 22(2):179-197.

Note: No comma after the surname.

No full stops after the initials.

Use capital letters in the title only where absolutely necessary.

Only title of journal is in italics.

No spaces between issue number, colon and page numbers.

You are welcome to use abbreviations for journals, but should you suspect that the reader will not know which journal is referred to, you may write the title out in full.

Books:

Vos J S

2002. Die Kunst der Argumentation bei Paulus. Studien zur antiken Rhetorik. Tübingen: Mohr Siebeck. WUNT 149. 
Note: No comma after surname.

No full stops after initials.

Use capital letters in the title only where absolutely necessary. Only title of book is in italics.

No space before colon after place of publication.

The series in which the book appears is mentioned at the end and not placed in brackets.

Articles in books with an editor:

ACHTEMeier P

1997. Finding the way to Paul's theology. In: J.M. Bassler (ed.), Pauline theology. Vol 1. Thessalonians, Philippians, Galatians, Philemon (Minneapolis: Fortress, SBLSS 4), pp. 3-21.

Note: The reference is similar to the one for an ordinary book, except that "In:" is added, the editor(s) is/are named and the reference to the place of publication, publisher and series is placed in brackets so that the reference to the page numbers reads more easily. Furthermore, pp. is used.

Newspaper reports:

When the author is not mentioned:

DIE KERKBODE

2001. Aborsie nie aanvaarbaar. 15 Junie, p. 23.

When the author is mentioned:

SMIT M

2002. Die pad voretoe. Die Volksblad 23 Julie, p. 2.

When the person concerned is mentioned:

Asmal K

2003. Nuwe onderwysbedeling. Die Volksblad 4 Desember, p. 9.

Web pages:

Web page (author and date of publication mentioned)

Le Roux K

2002. Teologie in 'n nuwe eeu. [Online] Retrieved from: http:// www.kerk.org.za/bib/dokumente/3.html [2003, 5 January]. 
Instructions to authors

Web page (no author)

Teologie in 'n nuwe eeu. 1989. [Online]. Retrieved from: http://www. kerk.org.za/bib/dokumente/3.html [2003, 5 January].

Web page (author; no date of publication)

Le Roux K

n.d. Teologie in 'n nuwe eeu. [Online]. Retrieved from: http://www. kerk.org.za/bib/dokumente/3/html [2003, 5 January].

16. The author of an article receives 10 reprints of his/her article as well as one free copy of the specific issue of the journal.

17. As Acta Theologica is an accredited journal, a page fee of R50 per page is levied. Such fees may be recouped from earnings on research publications. Authors do not bear the costs of articles, but receive accounts for submission to the management of the university or other institution where the author is employed. 